\title{
3. SIMILARITIES ACROSS THE CENTURIES: A COMPARISON BETWEEN TWO VOCAL WORKS BY BARBARA STROZZI AND PETER MAXWELL DAVIES
}

\author{
Rossella Marisi ${ }^{10}$
}

\begin{abstract}
Musical creativity may be expressed by composers in diverse ways: sometimes they compose fully original works, which are characterized by specific features making them unique. Other times, musicians may feel a particular affinity with colleagues who lived centuries before, or identify peculiar resemblances between the time they live in, and a previous epoch, such as similar cultural climate and approach to life: in these cases, composers may author pieces which show surprising similarities with those of some predecessors. The present study compares a work of the seventeenth century, composed by Barbara Strozzi, and one composed in the 1960s by Peter Maxwell Davies, highlighting their similarities.
\end{abstract}

Key words: Baroque, Expressionism, mad scene, melismatic passages, chromatism

\section{Introduction}

Musical creativity is expressed in ways that are, sometimes, fully original, and feature the work of a composer, making it unique. Other times, musical pieces written centuries apart, and in different countries, have surprising similarities: sometimes the second composer explicitly intends to recall the work of his predecessor. Occasionally, the tribute that the second musician pays to the first is implicit within the choice of the subject, musical form, type of instrumentation, or specific composition techniques. It is highly likely, however, that when a composer ideally connects its work to the one of a predecessor, he recognized similarities between the time he lives and the one his predecessor lived, such as cultural climate and approach to life. The present study aims at discovering similarities across the centuries, comparing a work of the seventeenth century, composed by Barbara Strozzi, and one composed in the 1960s by Peter Maxwell Davies.

\section{Historical framework}

The historic turning points characterizing the seventeenth century - the Economic Crisis in the Holy Roman Empire (1619-1623), the Thirty Years War in Germany (1618-1648), the Portuguese Restoration War against Spain (16401668), the revolts against the Spanish crown in the Netherlands (1568-1648), in Italy (1647), and in Catalonia (1640-1659), the Glorious Revolution in England (1688), the colonization of new continents, the overcoming of geocentrism, also called the 'Ptolemaic system', the spread of the Reformation, the request of social change, generated a new cultural climate characterized by the loss of the certainties which typified the Renaissance, and the spread of ambiguity and doubt. ${ }^{11}$ In the seventeenth century this revolution of the general feeling

\footnotetext{
${ }^{10}$ Assistant PhD. / "Niccolò Piccinni" Music Conservatory from Bari, Italy, email: rossellamarisi@hotmail.it
} 
reflected in the affirmation of a new style, which translated into paintings, sculptures, architectures, poetry, music, and theater the sense of marvel, wonder, amazement, but sometimes also of dizziness and qualm, that people felt facing the dramatic changes characterizing their epoch. The Baroque style abandoned consciously the brilliant, intellectual qualities of sixteenth-century art searching for a direct, simple, and theatrical appeal to the senses.

At first, the meaning of the word Baroque did not indicate a style but rather a departure from style, as whimsicality of taste or fashion. In fact, in 1777 the German writer Justus Möser equated "le goût baroc" to a crooked, distorted taste $^{12}$. Originally the term denoted works of art which were irregular to the point of being odd. Contrary to Renaissance's works of art, which developed the linear perspective, a system in which all objects and figures in a painting or in a bas-relief sculpture are rationally related in their proportions, giving the viewer a sense of order and serenity, Baroque art products created illusions of unlimited space, as figures ascending towards an infinite heaven, or fusions of pictorial, sculptural and architectural elements, causing ambiguous and misleading perceptions. $^{13}$

Indeed, the Swiss art historian Wölfflin characterized the Baroque as an art of dissolution into the infinite, an art of pathos, and contrasted these aspects of Baroque with the Renaissance's ideals of calm and beauty. A Baroque work of art aims, Wölfflin claims, at a different effect: it sets the customers into the tension of an emotional condition, wishing to enrapture the public with the influence of its direct and powerful impact. ${ }^{14}$ Wölfflin clearly inserted his own view in the traditional artistic theory conceiving the Baroque period as a time of conflict, and its art works as often asymmetric, extravagant, anti-rational and sometimes even grotesque - in short, characterized by a completely anticlassical style ${ }^{15}$.

In the field of visual arts, the baroque artist uses in an unusual way the laws on visual perception, creating oval domes and spiral-shaped lanterns, in this way contributing to alter habitual perceptions of space and to the creation of deception effects. ${ }^{16}$ Just alluding to these effects, in 1785 Francesco Milizia characterized the architectural works of Francesco Borromini as "delirio maggiore". ${ }^{17}$ Similar peculiarities characterized either Baroque visual artworks or music pieces: in a satirical review of Jean-Philippe Rameau's Hippolyte et Aricie, premiered in October 1733, which was printed in the Mercure de

\footnotetext{
${ }^{11}$ Hugh Trevor-Roper (1967), The Crisis of the Seventeenth century. Religion, the Reformation, and Social Change, Liberty Fund, Indianapolis

12 Justus Möser (1777), Harlekin oder die Vertheidigung des Groteske-Komischen. Neue verbesserte Aufl. Bremen, bey Johann Heinrich Cramer, 53.

13 James H. Beck (2000), Renaissance Art and Architecture, Microsoft Encarta Online Encyclopedia, http://autocww.colorado.edu/ toldy3/E64ContentFiles/PeriodsAndStyles/Renaissance.html. (accessed on 9 October 2017).

${ }^{14}$ Heinrich Wölfflin (1966), Renaissance and Baroque, Cornell University Press, Ithaca, 38.

${ }^{15}$ Werner Oechslin (2008), Wissensformen, Gta Verlag, Zürich.

16 John Picchione (2009), Baroque Poetry in Italy: deception, Illusion, and Epistemological Shifts, in Leslie Boldt-Irons, Corrado Federici, Ernesto Virgulti (2009), Disguise, Deception, Trompe-l’oeil. Interdisciplinary Perspectives, Petter Lang Publishing, New York, 61.

${ }^{17}$ Francesco Milizia (1785), Memorie degli Architetti antichi e moderni, Remondini, Venezia, vol 2, 158.
} 
France in May 1734, the anonymous critic insinuated that the most characteristic aspect of this opera was "du barocque", and described its features as follows: lacking a coherent melody, interspersed with dissonances, constantly changing key and meter, and made up by a series of every possible compositional device. ${ }^{18}$

Also the period straddling between the nineteenth and the twentieth centuries was characterized by dramatic events: the mechanization of labor, the rise of big cities and industrial regions, the resulting social transformation, and the first world war, provided psychological shocks to those who were not favorable to the innovations brought by the new industrialized world. ${ }^{19}$ Several scholars focused on "the alienation, reification and dehumanization of modern everyday life" ${ }^{20}$ and the fragmentation of the human personality taking place at the beginning of the twentieth century. Among them, the German sociologist Tönnies described the transition as a movement from natural communities founded on strong connections about their members (Gemeinschaft) to a fragmented society made up by egotistic individuals

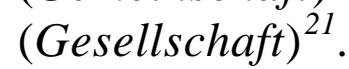

The adherents of Expressionism, the modernist movement originated in Germany at the beginning of the twentieth century, felt that they could not express their experiences and visions in traditional artistic forms, which reflected an ideal world of beautiful illusions. Therefore, being daily faced with the ugliness of industrial society, and experiencing feelings of unease, these artists were driven to create new art forms. ${ }^{22}$

Analogies between the baroque and the expressionist period were highlighted by different scholars: first and foremost Wölfflin, who recognized that his own interpretation of the Baroque was influenced by his present day experiences, affirming that one could hardly fail to recognize the affinity that his age bore to the Italian baroque. ${ }^{23}$ In a similar vein, Albert Erich Brinckmann wrote extensively on the baroque desire for expression that leads, finally, to the explosion of form, ${ }^{24}$ and characterized a new style that appeared around the end of the nineteenth century as Neubarock, clearly viewing modern art as a direct extension of the Baroque. ${ }^{25}$

\footnotetext{
${ }^{18}$ Mercure de France (1734), 'Lettre de $\mathrm{M}^{* * *}$ à Mlle*** sur l'origine de la musique’, May 1734, 868-870

${ }^{19}$ William Kelly (2003), Art and Humanist Ideals: Contemporary Perspectives, Macmillan Art Publishing, South Yarra, 52.

${ }^{20}$ Timothy W. Luke (1990), Social Theory and Modernity: Critique, Dissent and Revolution, Sage Publications, Newbury Park, 132.

${ }^{21}$ Ferdinand Tönnies (2011), Community and Society, Dover Publications, New York.

${ }^{22}$ William Kelly (2003), Art and Humanist Ideals: Contemporary Perspectives, Macmillan Art Publishing, South Yarra, 54-55.

${ }^{23}$ Heinrich Wölfflin (1966), Renaissance and Baroque, Cornell University Press, Ithaca, 87.

${ }^{24}$ Albert Erich Brinckmann (1919), Entwicklungsgeschichte der Skulptur in den romanischen und germanischen Ländern seit Michelangelo bis zum 18. Jahrhundert, Akademische Verlagsgesellschaft Athenaion, Berlin, vol I, 205-206.

${ }^{25}$ Albert Erich Brinckmann (1922), Plastik und Raum als Grundform künstlerischer Gestaltung, R. Piper, München, 75.
} 


\section{Barbara Strozzi and Peter Maxwell Davies: biographical hints}

Barbara Strozzi and Peter Maxwell Davies expressed in their pieces the feelings of disorientation and anxiety experienced by many artists and common people in the seventeenth and the twentieth centuries: we will highlight the similarities between Strozzi's cantata L'astratto op 8 n 4 and Davies's monodrama Revelation and Fall op. 31. The Venetian Barbara Strozzi, (16191677), likely the illegitimate daughter of librettist and poet Giulio Strozzi, came into contact very early with Monteverdi and Cavalli, who became her teacher. In Venice she attended the meetings of some intellectual discussion groups, and in particular the Accademia degli Unisoni, established by her father, which included nearly all the prominent intellectual patricians of Venice.

There she often performed her own pieces: her beauty, wit, and outstanding singing voice were important attractions in those meetings ${ }^{26}$. She composed eight volumes of cantatas, ariettas, and madrigals, but never sung or composed an opera. ${ }^{27}$ The English composer Peter Maxwell Davies (1934-2016) studied in Italy with Goffredo Petrassi, and at Princeton with Roger Sessions, Milton Babbitt and Earl Kim. He held the position of associate conductor/composer at both the BBC Philharmonic and Royal Philharmonic orchestras and has been one of the foremost musicians of the present time. He was passionately committed to the social responsibility of the composer and the concept of music as a social force. ${ }^{28}$

\section{L'astratto and Revelation and Fall: a comparative view}

Both L'astratto and Revelation and Fall are soliloquies; a soliloquy is a particular kind of speech often used in drama, in which a character speaks to himself, usually while alone on stage and thus unheard by other characters. In this kind of speech a character expresses his thoughts and feelings, thereby also sharing them with the audience, often giving the illusion of letting the public in on his unspoken reflections. In some sense, a soliloquy may hint to the absence of a social group of reference, with whom the character could share his feelings: this in turn could show that the story is set in a period in which individualism and egoism take priority over a sense of community, detaining the character from telling his secrets to anyone else. The music of a vocal piece centered on a soliloquy may be quiet and lovely if the character is having a daydream, or tumultuous, if he is living a nightmare, or it can express alternatively sadness and excitement if the character is assailed by overwhelming emotions and either suffers hallucinations or plans an extreme course of action, for instance to commit suicide or murder ${ }^{29}$.

Taking into consideration the two pieces on the whole, we notice that in

\footnotetext{
${ }^{26}$ Wendy Heller (1999), 'Tacitus Incognito: Opera as History in L'incoronazione di Poppea', Journal of the American Musicological Society, 52(1), 39-96.

${ }^{27}$ Isabelle Putnam Emerson (2005), Five Centuries of Women Singers, Praeger, Westport and London, 36.

${ }^{28}$ Sir Peter Maxwell Davies, http://www.maxopus.com/life_career.aspx (accessed on 9 October 2017)

${ }^{29}$ Enrique Alberto Arias (1999), Reflections from a Cracked Mirror, 137 in Enrique Alberto Arias, Susan M. Filler, William V. Porter (1999), A Compendium of American Musicology. Essays in Honor of John F. Ohl, Northwestern University Press, Evanston.
} 
L'astratto the music shifts rapidly between contradictory feelings, an argument in favor of the hypothesis that the character suffers from bipolar disorder, and consequently the cantata features a mad scene. Research stressed that in choosing for his Revelation and Fall the text of Georg Trakl, which is characterized by febrile oneiric visions, Davies laid the foundations for an "equivalent of an operatic mad scene". ${ }^{30}$

The second peculiarity characterizing both pieces is that they require from the performer the use of different styles of delivery: in L'astratto the singer performs at time a spoken recitativo ${ }^{31}$, at times he will sing with straight-tone timber, ${ }^{32}$ or various kinds of vibrato, among which natural vibrato. Concerning the vibrato, it is important to recall that during the seventeenth century, vibrato was regarded as an ornament. As a result, in some occasions, seventeenthcentury singers used less vibrato and a faster one than modern singers usually $\mathrm{do}^{33}$. One reason for this was that performance venues were generally characterized by more reverberation than the present-day ones ${ }^{34}$. Other reasons to use a natural vibrato are linked to specific points in the melody, such as "a dissonance, a leading tone, a tone approached by chromatic half step, or a particularly expressive interval such as a tritone.” ${ }^{35}$ The opportunity to choose among different varieties of vibrato gives singers the opportunity to accord it to the pace of the music, but also to put in relief the emotional intensity of the text. $^{36}$

In Revelation and Fall the composer requires to use different voices beside singing, such as Sprechgesang, whispering, and even screaming through a megaphone ${ }^{37}$. A third characteristic shared by both pieces is the use of the rhetorical artifice called figura suspirans: a passage is introduced by a short rest, which gives the sensation of a quick breath, alluding to a sigh, gasp, groan, or an expression of longing. ${ }^{38}$

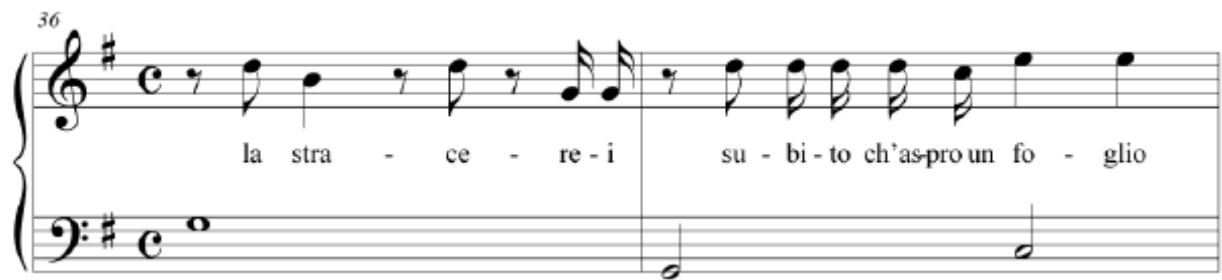

Barbara Strozzi, L’astratto

\footnotetext{
${ }^{30}$ Philip Rupprecht (2015), British Musical Modernism: The Manchester Group and their contemporaries, Cambridge University Press, Cambridge, 326.

${ }^{31}$ This occurs in measures 19, 36-37, 55-56,79-80, 93, 110, 118-124.

${ }^{32}$ This occurs for instance in measures 5-10.

${ }^{33}$ Julianne Baird (1997), "Solo Singing 2,” in A Performer’s Guide to Seventeenth-Century Music, ed. Stewart Carter, Schirmer Books, New York, 38.

${ }^{34}$ John Spitzer and Neal Zaslaw (2004), The Birth of the Orchestra. History of an Institution, 1650-1815, Oxford University Press, New York, 368.

${ }^{35}$ Ibidem

${ }^{36}$ Martha Elliott (2007), Singing in Style: A Guide to Vocal Performance Practices, Yale University Press, New Haven and London, 16.

${ }^{37}$ Revelation and Fall, Short Note by Paul Griffiths, http://www.maxopus.com/work_detail.aspx?key=200 (accessed on 9 October 2017).

${ }^{38}$ Dietrich Bartel (1997), Musica Poetica: Musical-Rhetorical Figures in German Baroque Music, University of Nebraska Press, Lincoln and London, 382.
} 


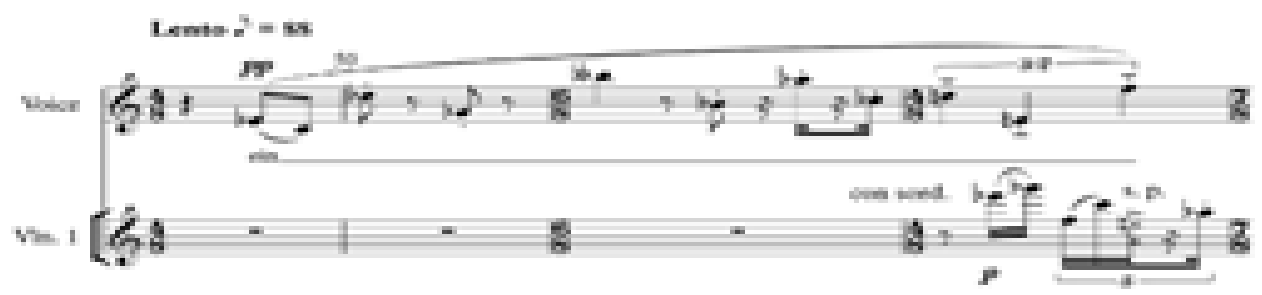

Peter Maxwell Davies: Revelation and Fall

A further peculiarity shared by both pieces is the use of melismatic passages.

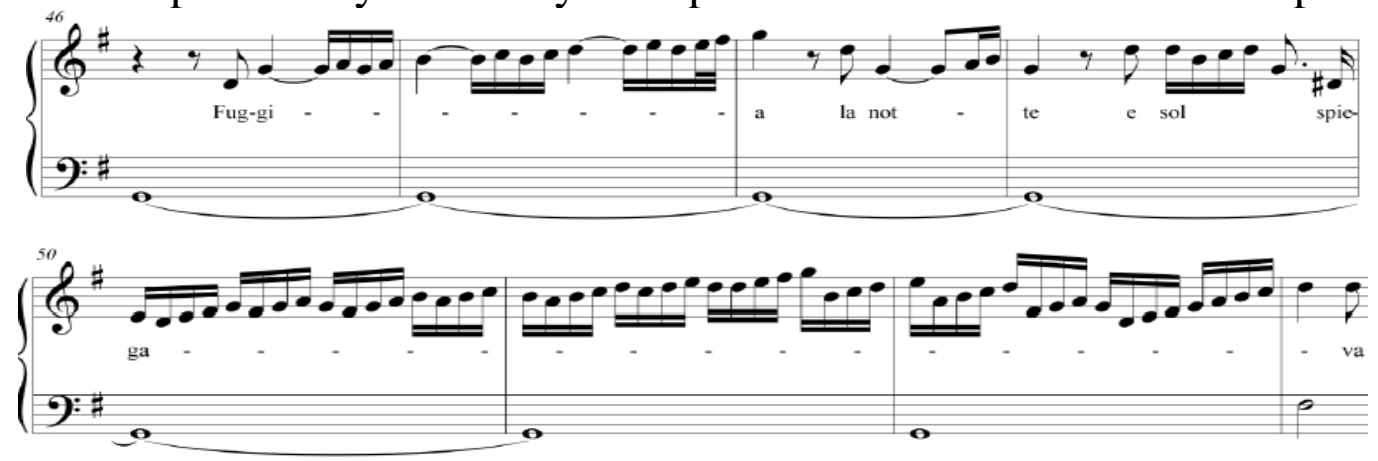

Barbara Strozzi, L’astratto

Ammt $x^{5}=m$
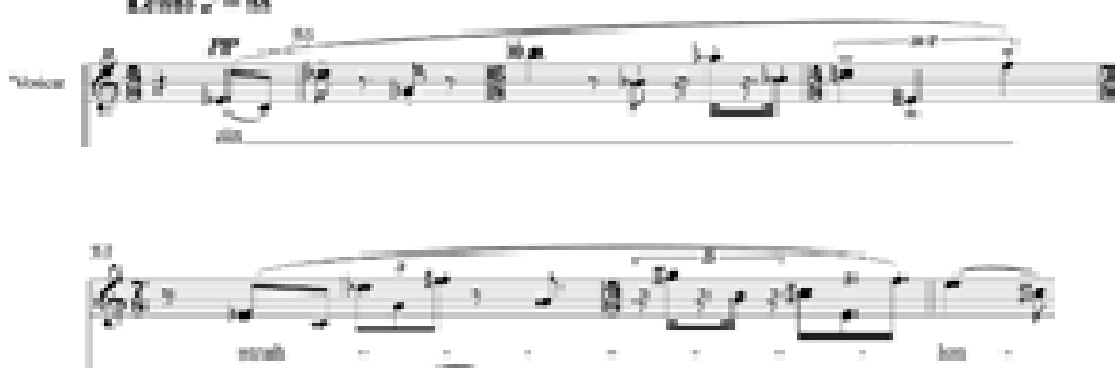

Peter Maxwell Davies: Revelation and Fall

The last characteristic shared by both pieces is the sense of anguish, which Strozzi stresses in measure 6 through a descending tetrachord and chromatism.

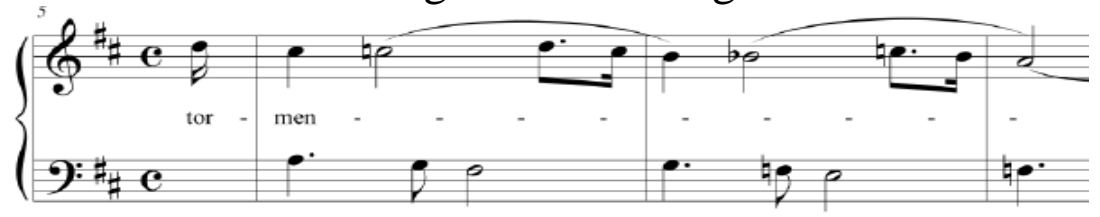

Barbara Strozzi: L'astratto

Davies even makes use of descending portamento on fourth intervals and hyperchromatism on quarter-tone intervals in slow descending passages.
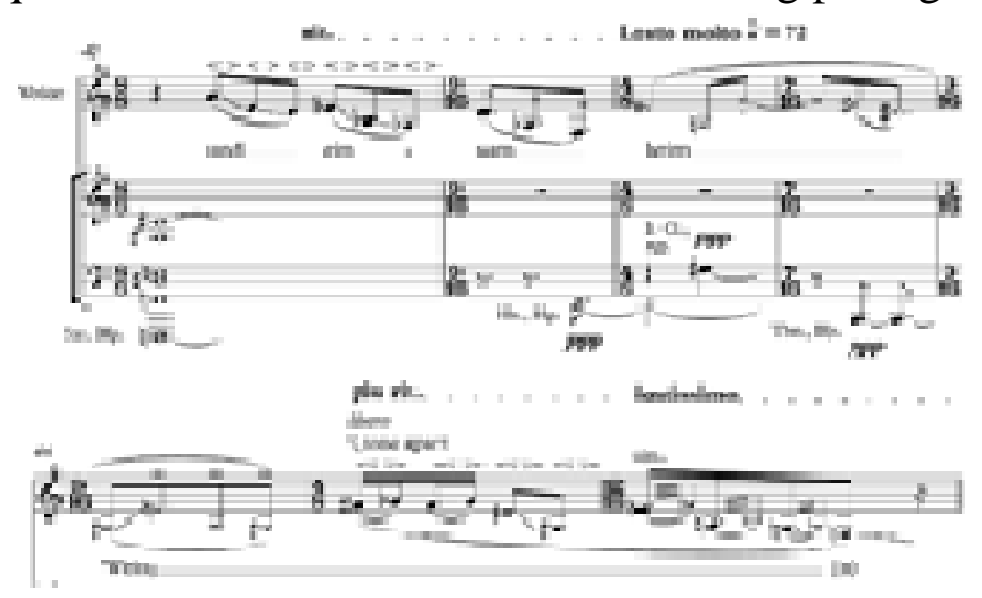

Peter Maxwell Davies, Revelation and Fall 
Moreover, it is interesting to mention that the cover of both editions of Davies's published score sport an engraving of Edvard Munch's The Scream, a painting which can be considered as the true embodiment of Expressionist anxiety. ${ }^{39}$

\section{Conclusions}

Similarities in creative products written centuries apart and in different countries may depend on a range of factors: the present study has shown that certain analogies in the socio-cultural context in which the works of art have been created, and their adherence to determined rhetorical conventions can, as a matter of fact, create a common substratum originating shared artistic choices. When the second composer expressly mentions the work composed by another musician, we know with certainty that there was an explicit intention to establish a connection. On the other side, if this explicit reference is missing, it cannot be concluded that the second work represents an implicit allusion to the previous work, but at the same time, it cannot be excluded that the previous work has fascinated the modern composer, in such a way that he has unconsciously answered to this input adopting a similar style. Therefore, studying the similarities between art works originated in different epochs and countries is in any case a way to better understand the analyzed works and the artistic choices made by their authors.

\section{Bibliography}

1. Arias Enrique Alberto (1999), Reflections from a Cracked Mirror, 137 in Arias Enrique Alberto, Filler Susan M., Porter William V. (1999), A Compendium of American Musicology. Essays in Honor of John F. Ohl, Northwestern University Press, Evanston.

2. Arias Enrique Alberto, Filler Susan M., Porter William V. (1999), A Compendium of American Musicology. Essays in Honor of John F. Ohl, Northwestern University Press, Evanston.

3. Baird Julianne (1997), "Solo Singing 2," in A Performer's Guide to Seventeenth-Century Music, ed. Stewart, Carter, Schirmer Books, New York

4. Bartel Dietrich (1997), Musica Poetica: Musical-Rhetorical Figures in German Baroque Music, University of Nebraska Press, Lincoln and London.

5. Beck James H. (2000), Renaissance Art and Architecture, Microsoft Encarta OnlineEncyclopedia, http://autocww.colorado.edu/ toldy3/E64ContentFiles/PeriodsAndStyles/Renaissance.html. 6. Boldt-Irons Leslie, Federici Corrado, Virgulti Ernesto (2009), Disguise, Deception, Trompe-l'oeil. Interdisciplinary Perspectives, Petter Lang Publishing, New York.

\footnotetext{
${ }^{39}$ Philip Rupprecht (2015), British Musical Modernism: The Manchester Group and their contemporaries, Cambridge University Press, Cambridge, 327.
} 
7. Brinckmann Albert Erich (1919), Entwicklungsgeschichte der Skulptur in den romanischen und germanischen Ländern seit Michelangelo bis zum 18. Jahrhundert, Akademische Verlagsgesellschaft Athenaion, Berlin, vol I.

8. Brinckmann Albert Erich (1922), Plastik und Raum als Grundform künstlerischer Gestaltung, R. Piper, München.

9. Elliott Martha (2007), Singing in Style: A Guide to Vocal Performance Practices, Yale University Press, New Haven and London.

10. Heller Wendy (1999), 'Tacitus Incognito: Opera as History in L'incoronazione di Poppea', Journal of the American Musicological Society, 52(1), 39-96.

11. Kelly William (2003), Art and Humanist Ideals: Contemporary Perspectives, Macmillan Art Publishing, South Yarra.

12. Luke Timothy W. (1990), Social Theory and Modernity: Critique, Dissent and Revolution, Sage Publications, Newbury Park.

13. Mercure de France (1734), 'Lettre de $\mathrm{M}^{* * *}$ à Mlle*** sur l'origine de la musique’, May 1734, 868-870.

14. Milizia Francesco (1785), Memorie degli Architetti antichi e moderni, Remondini, Venezia, vol 2.

15. Möser Justus (1777), Harlekin oder die Vertheidigung des GroteskeKomischen. Neue verbesserte Aufl. Bremen, bey Johann Heinrich Cramer.

16. Oechslin Werner (2008), Wissensformen, Gta Verlag, Zürich.

17. Picchione John (2009), Baroque Poetry in Italy: deception, Illusion, and Epistemological Shifts, in Boldt-Irons Leslie, Federici Corrado, Virgulti Ernesto (2009), Disguise, Deception, Trompe-l'oeil. Interdisciplinary Perspectives, Petter Lang Publishing, New York.

18. Putnam Emerson Isabelle (2005), Five Centuries of Women Singers, Praeger, Westport and London.

19. Revelation and Fall, Short Note by Paul Griffiths, http://www.maxopus.com/work_detail.aspx?key=200 (accessed on 9 October 2017).

20. Rupprecht Philip (2015), British Musical Modernism: The Manchester Group and their contemporaries, Cambridge University Press, Cambridge.

21. Sir Peter Maxwell Davies, http://www.maxopus.com/life_career.aspx (accessed on 9 October 2017)

22. Spitzer John and Zaslaw Neal (2004), The Birth of the Orchestra. History of an Institution, 1650-1815, Oxford University Press, New York.

23. Tönnies Ferdinand (2011), Community and Society, Dover Publications, New York.

24. Trevor-Roper Hugh (1967), The Crisis of the Seventeenth century. Religion, the Reformation, and Social Change, Liberty Fund, Indianapolis.

25. Wölfflin Heinrich (1966), Renaissance and Baroque, Cornell University Press, Ithaca. 